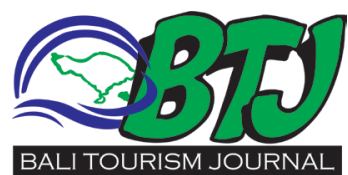

\title{
A history of the King in the sky: Balinese Kite Festival
}

\author{
Putu Bagus Anggaraditya ${ }^{1}$
}

\section{ABSTRACT}

'Pelangi' (Persatuan Layang-Layang Bali) or Bali Kite Association, held a kite flying festival from early July until the end of October 2017. It aims to preserve culture, stimulate creativity and grow bond and togetherness among societies as well as become a tourist attraction. Government supports the festival as means of cultural preservation as well as a tourist attraction for domestic and foreign. However, as time goes by, the land to play kite is getting narrower due to development. Therefore, attention and participation by local government and society are needed to maintain the availability of land for the sake of the preservation of this cultural festival.

Keyword: Bali Kite Festival, Culture Preservation

Cite This Article: Putu Bagus Anggaraditya, A history of the King in the sky: Balinese Kite Festival. Bali Tourism Journal (BTJ)2017, 1 (1): 3-6

\section{INTRODUCTION}

Kites have its own place in the hearts of people in Bali. They believe that the kite was firstly introduced by Rare Angon, which is the embodiment of Lord Shiva. Rare Angon means a shepherd boy. In 'kite season' or after harvest, Rare Angon descends to Earth while playing the flute. The pipe is used by him to call the wind. This story then becomes habit after the harvest season by the farmers, especially the shepherd boy, to play kite while keeping his cattle. ${ }^{1}$

Based on these legends, the Balinese take the tradition seriously. It is proved by kite festival is held annually in Bali. 'Pelangi' (Persatuan LayangLayang Bali) or Bali Kite Association, held a kite flying festival from early July until the end of October 2017. Each year, the festival always attracts local and international

participants to participate. Denpasar Mayor IB Rai Dharmawijaya Mantra said the festival is always anticipated every year. It is one of the big and exciting events because it has similar cultural uniqueness as the Bali Arts Festival. He also revealed that kite competition is a form of creativity and requires a sense of bond and togetherness in its implementation. This activity should continue to developed and maintained as a means of culture reinforcement as well as attracting foreign tourists.

\section{THE EVENT}

The first kite flying festival in 2017 is the 7 th Pitik Kite Festival. This festival was held on 1-2 July 2017, in Carik Abasan Sari, Banjar Pitik Pedungan, Denpasar, Bali. Pitik Kite Festival Chairman
Committee, I Putu Adi Purnama Putra, revealed that it is hoped from this activity may stimulate a creative generation in creating kites and most importantly can preserve the art and culture. Adi added, traditional Balinese kite has a giant size and has grown over the years (Figure 1). The extent of about 4 meters and 10 meters in length. One type of kite, Janggan, a typical dragon kite with an amazing ribbon tail and has 100 meters in length or more (Figure 2).

In addition to the unusual size, kites in Bali are also equipped with sound instruments called Guwang that will vibrate when exposed to the wind and produce buzzing sounds that can be heard from a distance. There are also 'Creation Kite' with 3D shapes and specific designs such as Hindu Gods, vehicles; such as cars and motorcycles, mascots and sponsors logo. During the event, there is a gamelan accompaniment to increase the festival spirit, especially when the kite is flown and when it goes down.

Denpasar Mayor, IB Rai Dharmawijaya Mantra said that the Kite festival takes place along the east coast of Padanggalak, the northern part of Sanur. It is held annually between July and October especially when

'Windy Season' comes. Dharmawijaya Mantra said the festival is organized by 'Setia Remaja Pedungan' and targeting 1,000 kite participants in Bali, with categories for children and adults. Kites that are contested consist of various types of groups; such as Bebean classes for children, adults and big size, Janggan and Janggan Buntut Classes, Pecukan and 'creations kite'. In addition, also held a photography contest." 


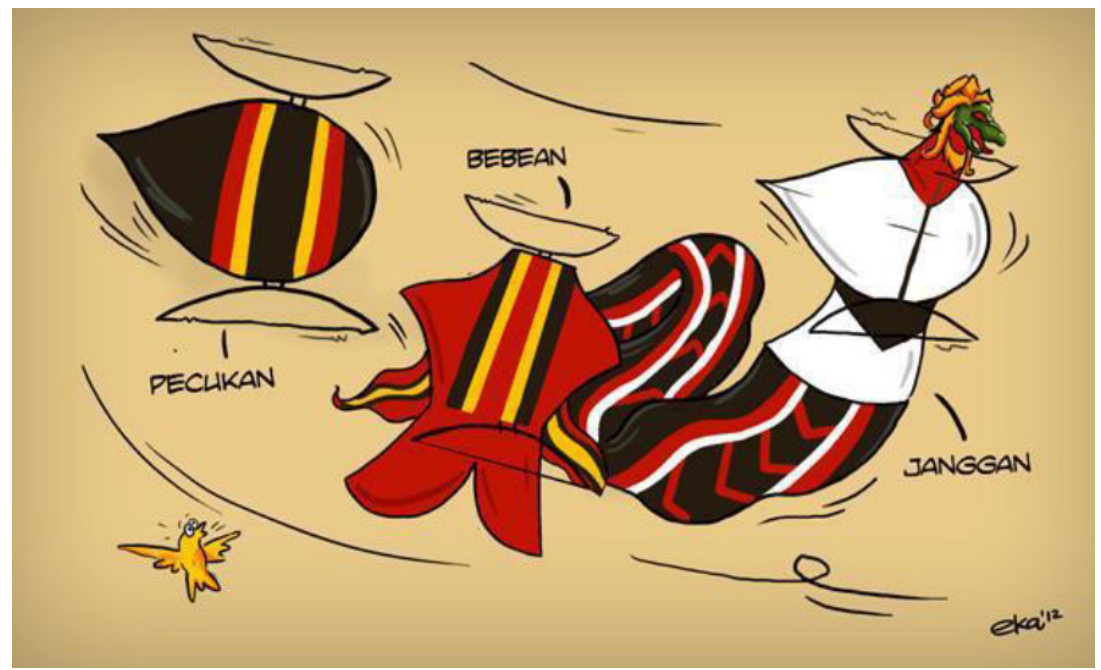

Figure 1 traditional Balinese kite has a giant size and has grown over the years $^{2}$

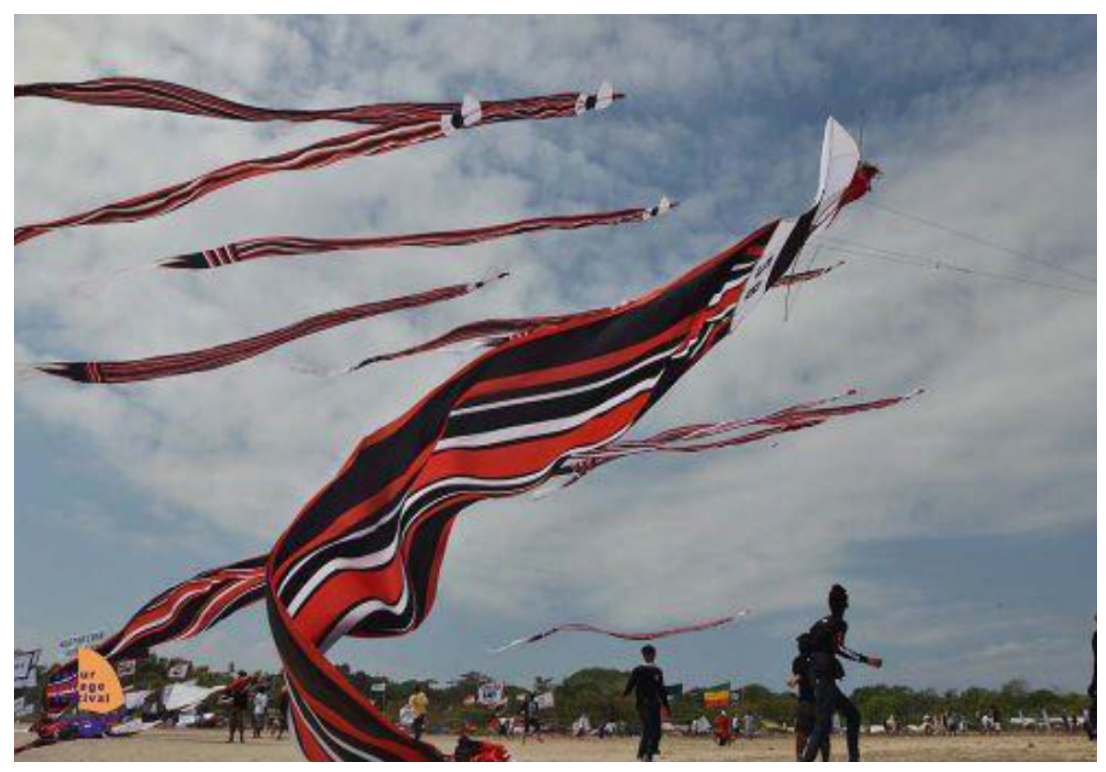

Figure 2 Janggan, a typical dragon kite with an amazing ribbon tail and has 100 meters in length or more

Tourism Minister Arief Yahya positively welcomed the possibility of holding a kite festival. He hopes that events continue to be preserved, then the promotion needs to be more intensified. Through media and social media, it is expected participants from foreign countries may participate. Not only Pitik Kite Festival, but similar festivals are also going to be held in Bali during July-October this year. Playing kite is exciting for anyone, including foreign tourists.

The festival that has been held for $7^{\text {th }}$ time clearly will attract thousands of tourists attention who are on holiday in Bali. Arief Yahya explained he has a particular reason why the festival will attract a lot of tourists. July is peak season thus Bali is flocked by tourists. Idul Fitri and school holiday are perfect moments for the Festival. With thousands of visitors, it will give a very positive impact on the outside world. He firmly believes after this event; tourists will remember the Bali with Kite, and come back to Bali. ${ }^{3}$

The next event is the 39th Bali Kite Festival. It is held at Padang Galak Beach, Denpasar, on July $8^{\text {th }}$ to $9^{\text {th }}$. Ni Putu Gayatri, head of the Tourism Ministry's Tourism Ministry's manmade tourism division stated the festival is a partnership event between Ministry of Tourism and the Indonesian Kites Association (PELANGI).

Approximately, 1,000 kites were taking part. It also aimed to attract 1,000 international tourists and 5,000 local tourists. ${ }^{4}$ Meanwhile, Esthy Reko Astuti, deputy for tourism development at the ministry, said "This kite competition is a way to preserve the culture of the people in Bali. The Balinese people are very creative," she added, "The competition was meant to show the people's creativity while preserving the traditions as a way to face global challenges. It is also an attraction for foreign tourists".

After huge success in Padang Galak on 8-9 July, a similar event will be held again on 22-23 July 2017 in Sanur Village. Bebean, Janggan, Pecukan, and creations are classes that are going to be contested. But there is a slightly different requirement asked by committee compared to the previous events. The board set two conditions for participants who want to participate. Kadek Suprapta Meranggi, Chairman of the Contest, said that two conditions are required to be able to participate in the competition; the kite must be able to be disassembled and must be environmentally friendly.

According to Kadek Suprapta, every time Sanur kite competitions are held, it always creates traffic congestion due to the large size of the kites. While for environmentally friendly terms that are required, means participants must keep their environment clean and not leaving any garbage around the area. "In the assessment, this time cleanliness is going to be one of consideration point that should be aware of" he explained. The committee has been holding cooperation with NGO 'Malu Dong. They are invited to socialize about maintaining cleanliness at the venue. Cleanliness factor is crucial to be a concern because kite contest participants every year continue to increase. For this year, it is estimated to reach 1,800 participants. ${ }^{6}$ After that, it is continued by 'Sanur International Kite Festival' on August $3^{\text {rd }}$ to $8^{\text {th }} 2017$. This international festival organized with the theme 'Bhinneka Tunggal Ika.' It is Informed that there would be 26 participating countries enliven the event. 


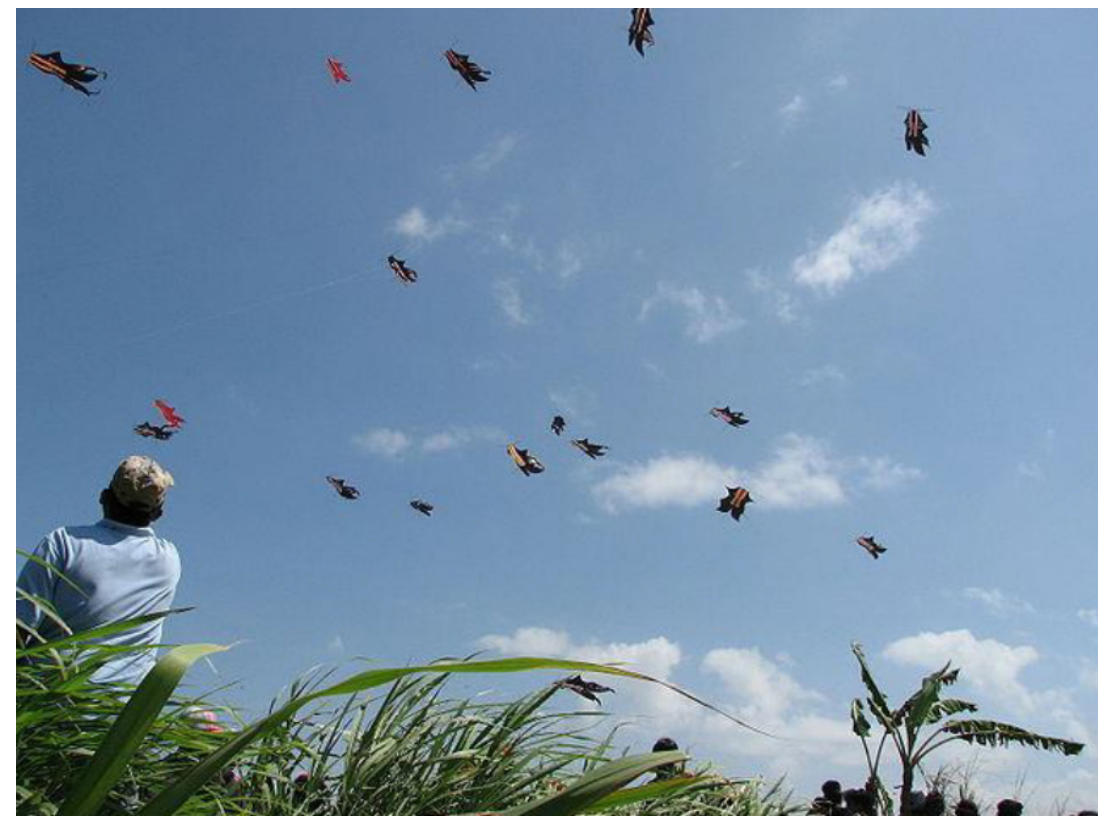

Figure 3 the Sanur Village Festival ${ }^{9}$

'Sanur International Kite Festival' is one of the programs of Sanur Village Festival (SVF) that combines art, aerodynamics, culture, including philosophy, history and innovative imagery.

This program was designed in conjunction with the coming of monsoons as well as the SVF agenda, making this event united between nature and the celebration agenda of Sanur society. Sanur itself has long been known as a leading village in the world of kites. Traditional and contemporary kites that use a variety of materials, from raw form to the latest and explore the contemporary issues, both in cultural traditions to present day life. The kite view in SVF is always changing. Creative work of local, national and international creators always give the characteristic according to the themes offered by the committee.

Chairman of SVF, Ida Bagus Gde Sidharta Putra or familiarly called Gusde, said the potential of a kite in Sanur that has been known to the world even an international kite circuit can be coupled with the connectivity of the creative and tourism industries. "In the month of the kite season any hotel can show off a kite that can become a new icon for the world of tourism," he said. Gusde also believes, there will be an interaction between tourists with kites that they see. After that, the opportunity to create a followup product from exotic items to kites that can be marketed directly. "The kite is not just a passion or joy, but more than that, it can economically increase people's income, which is being designed by the Sanur Village Festival, although, in reality, the business transactions of kites are running by themselves," Gusde added. ${ }^{8}$

\section{NO AREA LEFT}

Behind this year's festivities, there is apparently rumblings about an endangered kite tradition. Padang Galak Beach is on the northern end of Sanur, a seaside area under Denpasar administration, popular with tourists and expats. The beach is the main site of the Bali Kite Festival, an annual kite festival where traditional giant flights are competitively flown. Sanur's Padang Galak Beach is a favorite amongst the kite-flyers in Bali, but talk of a potential hotel or another development project in the spot made some members of the local 'kite community' worried about the end of 'limited open space' left in the Area." "Another of Sanur's beaches, Mertasari, which several times being used as a venue, is getting narrow because of hotels and shop development around the area. Now, the fear is for Padang Galak" said Made Yudha, the second chairman of the Bali Kite Association. According to Yudha, investors should not be allowed to build for commercial purposes on kite-flying spaces, because of the sacredness of the area. He emphasized the provincial government must defend this place as a green open space. "Imagine, if this keeps happening, it would be a shame for our next generation, "he added.

However, no matter the perception of the area as "sacred" by some, city zoning officials see things differently. Kadek Kusuma Diputra, head of DPMPTSP, the Denpasar Licensing Agency said "Padang Galak is a "tourism zone" not a "green zone". Meanwhile, Diputra recently revealed that some investors would build entertainment venues, such as malls and other entertainment centers in Denpasar. However, he did not specify who is behind the projects and where exactly in Denpasar the building would be. However, the site does not sound like it would be Padang Galak. Diputra says there have not been any applications filled form development permits in the kite-playing area of Padang Galak. But the spot is up for grabs, according to the official. Diputra said "What is clear to me is that it is a tourism zone,"

Padang Galak beach kite playing field, Kesiman, Denpasar, which has been controlled by investors got a response from Denpasar Mayor, Ida Bagus Rai Dharmawijaya Mantra. In principle, the number one man in Denpasar City Government said if there is any development in the area, they should involving Desa Pekraman Kesiman. "I have received a response from community leaders of Kesiman. They will hold the first meeting because it is a sacred area, "said Rai Mantra.

Rai Mantra claimed he did not know for sure who is the investor controlling the land in Padang 
Galak, Kesiman. He suggested that Desa Pakraman Kesiman makes perarem, or rules to protect the sacred area and pamelisan beach area of Padang Galak. Even, if later there would be built tourist accommodation and others, according to Rai Mantra, it must still be based on the approval of the local Desa Pakraman. Head of eastern Denpasar district, Dewa Puspawan also acknowledged that the land in Padang Galak had been owned by private. Puspawan mentioned from hectares of land in Padang Galak, some belong to the provincial government of Bali, and some belongs to investors.

Some of the so-called investors who possessed area in Padang Galak, including the MercedesBenz Dealer Head, Hartono, and Akasaka Music Club Boss, Jerry Filmon. In fact, Jerry had admitted that he had land in Padang Galak. The news about Padang Galak area has been possessed by investors became viral and got responses from thousands of Rare Angon or Kite Enthusiast through social media both Instagram and Facebook. They mostly reject any construction in the kite-playing arena. ${ }^{10}$

\section{CONCLUSION}

The Bali Kite Festival is an event that always awaited. As an event to grow the value of bond and togetherness, this activity also stimulated the creativity of youth in creating various types of kites. The government supports this annual festival as a means of cultural preservation as well as a tourist attraction for domestic and foreign. However, as time goes by, the land to play kite is getting narrower due to development. Therefore, attention and participation by local government and society are needed to maintain the availability of land for the sake of the preservation of this cultural festival.

\section{REFERENCES}

1. Jaya, PYA.LAYANG-LAYANG TRADISI BUDAYA bali "RARE ANGON SEJATI (R.A.S)". Academia Edu. https:// www.academia.edu/19793348/ARTIKEL_LAYANGLAYANG_TRADISI_BUDAYA_BALI_R_A.S_Rare_ Angon_Sejati_

2. http://colekpamor.blogspot.co.id/2016/01/rare-angonsejarah-layangan-tradisional.html

3. Diah. Bali Sebentar Lagi Bakal Dihebohkan Pitik Kite Festival 2017.Bali Post.2017. http://www.balipost.com/ news/2017/06/28 /12984/Bali-Sebentar-Lagi-BakalDihebohkan...html

4. Anonymous.Bali holds 39th Bali Kite Festival.The Jakarta Post.2017. http://www.thejakartapost.com/travel/2017 /07/10/bali-holds-39th-bali-kite-festival.html

5. Anonymous.Kite Festival Awes Tourists on Bali's Padanggalak Beach.Jakarta Globe.2017. http://www. jakartaglobe.beritasatu.com/fea tures/kite-festival-awestourists-on-balis-padanggalak-beach/

6. Gentur Putro Jati. Festival Layang-layang Sanur Siap Digelar 22-23 Juli.CNN Indonesia.2017.https://www.cnnindonesia. com/gaya-hidup/20170613094606-269-221298/festivallayang-layang-sanur-siap-digelar-22-23-juli/

7. http://www.sanurvillagefestival.com/uploads/image/ gallery/10.jpg

8. Indah Handayani. 26 Negara Ikuti Sanur International Kite Festival.Berita Satu.2017. http://www.beritasatu.com/gayahidup/441536-26-negara-ikuti-sanur-international-kitefestival.html

9. Anonymous. Sanur's Padang Galak Beach could be the site of another hotel or project, kite-flyers fear end of open space in area. Website: Coconuts Bali.2017. https:// coconuts.co/bali/news/sanurs-padang-galak-beach-siteanother-hotel-project-kite-flyers-fear-end-open-spaceareal

10. I Wayan Erwin Widyaswara. Lahan Bermain Layang-layang di Padang Galak Dikuasai Investor? Begini Komentar Rai Mantra.Tribun Bali.2017. http://bali.tribunnews. com/2017/07/10/lahan-bermain-layang-layang-dipadang-galak-dikuasai-investor-begini-komentar-raimantra

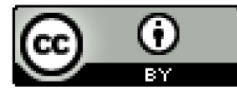

This work is licensed under a Creative Commons Attribution 